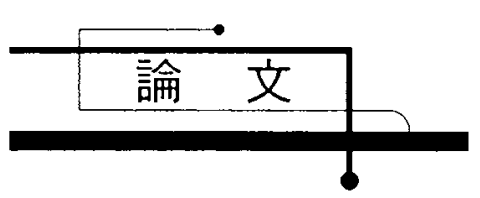

\title{
GPU を用いた固体粒子を含む固気液三相流の大規模シミュレーション*
}

\author{
Large-Scale Simulation of Gas-Liquid-Solid Multiphase Flow on GPU Cluster
}

\author{
小野寺 直 幸** 青 木 尊 之淿 \\ ONODERA Naoyuki AOKI Takayuki
}

\begin{abstract}
Numerical simulation of gas-liquid-solid interaction is one of the most challenging themes in CFD (Computational Fluid Dynamics). In order to understand the detail of the interface deformation and separation, it is necessary to carry out high-order accurate and large-scale CFD simulations. We have developed a CFD code based on a novel interface capture method, AMG-BiCGSTAB solver, 5th-order WENO scheme, and immersed boundary method (IBM). The code is written in CUDA, and the GPU kernel function is tuned to achieve high performance and good scalability on the TSUBAME supercomputer. It has become possible to carry out large-scale multiphase flow simulations. In a violent air-water flow, small splashes by collision of a particle are described clearly, and good performance scalability is also shown for multi-GPU computing.
\end{abstract}

Keywords: GPU, Large-scale simulation, Fluid-structure interaction, Multiphase flow

\section{1. 緒 言}

現在、様々な工学分野において固気液三相流の直 接計算の必要性が高まっている。物体との相互作用 による気液界面の変形・分離を高精度に解析するた めには、非常に多くの計算資源と計算時間が必要で あり、大規模高速計算が必須となる。GPU (Graphics Processing Unit) は非常に高い演算性能と広いメモ リバンド幅を持ち、GPU を利用した科学技術計算 を行う事で、今まで困難であった大規模計算が可能 となる $[1,2]$ 。一般的に、複雑境界を取り扱う数值計 算ソフトウエア等 $[3,4]$ においては、物体境界形状と 格子配置が一致する非構造格子を用いた解析が広 く行われている。しかし、非構造格子を用いた計算 では、メモリアクセスが不連続であり、メモリの間 接参照が必要となるため、計算効率の低下が懸念さ れる。さらに、移動物体を含む問題においては、計 算格子の再生成の必要があり、大きなオーバーヘッ ドを伴う。

格子配置が物体の形状に依存せず、直交格子点上 に複雑物体境界が表現可能な手法として、Immersed
Boundary 法 (IBM) が開発されてきた[5,6]。IBM では、局所的なメモリ参照を行うため、計算効率が 良く並列計算にも適している。

本研究では、IBM を適用した気液二相流の解析 手法に対して、GPU を用いた高速化技術を導入す る事で、高効率な大規模並列計算手法を提案する。 東京工業大学のスーパーコンピューターである TSUBAME を用いた、大規模並列計算の性能測定を 行うと共に、固気液三相流の連成解析を行い、今ま で解析が困難であった大規模解析を実施する。

\section{2. 気液二相流の解析手法}

\section{1 支配方程式および物理量配置}

界面捕獲法を用いた気液二相流の解析手法とし て、非圧縮性 Navier-Stokes 方程式に対して、気相 と液相で物性值を切り替える一流体モデルを用い た。計算中では気液両相は区別されず、単相の流 体と同様に扱われる。気液界面の識別関数には流 体率を、物体の識別関数には固体表面からの符号 付き距離関数を用いて解析を行った。計算格子は

* 2013.11.7 受付

** 東京工業大学学術国際情報センター † 152-8550 東京都目黒区大岡山 2-12-1-i7-3

TEL: (03)5734-3575 FAX: (03)5734-3276 E-mail: onodera@sim.gsic.titech.ac.jp 
等間隔直交格子を設定し、速度等のベクトル量はセ ル境界面上に定義し、圧力・流体率・符号付き距離 関数などのスカラー量はセル中心に定義する Staggered 変数配置を用いた。物体を符号付き距離 関数により表現する事で、直交格子を用いた解析 が可能となり、高い計算効率と並列化効率を達成 できる。

\section{2 空間離散化手法}

計算手法として、自由界面の捕獲手法は気液界 面の変形・分離を精度良く捉えることが可能な THINC/WLIC 法[7]を、速度場の計算手法として 二相流解析において実績のある丹ら[8]の解析手 法を採用した。具体的には、速度等の移流項には、 安定かつ高精度な 5 次精度 WENO 法[9-11]を、非 移流には 2 次精度の中心差分法を、表面張力項に は Brackbill の CSF(Continuous Surface Model) モ デル[12]を用いる。本研究では、それらの手法に対 して複雑な物体形状と物体の運動が表現可能な IB M [5,6]を適用することで、固気液三相流の解析 手法を構築した。

本研究において、す心゙ての物理量の時間発展計 算は GPU 上にて行われ、反復計算が必要となる 圧力 Poisson 方程式に対しては、みずほ情報総研 株式会社のAMG-BiCGSTAB をGPU へ拡張し たものを用いることで高速化を行った。

\subsection{IBM による物体表現手法}

IBM は格子点上の物理量 $(q)$ に物体力を作用さ せることで、物体から流体一の影響を表現する。 物体形状は物体表面からの符号付き距離関数 $(\phi)$ で与えられ、物理量は物体表面上にて境界条件が 満たされる。ここで、Fig. 1 の様に物体境界 $(\phi=0)$ が計算セル内にある場合を考える。ここで、ベク トル $\vec{n}$ は、符号付き距離関数の勾配ベクトルであ る。下付き添字 $f$ の物理量は、流体側で補間され る物理量、下付き添字 $b$ の物理量は物体境界面上 の物理量となる。下付き添字 $s$ の物理量は、物体 内の格子点上に定義され、境界条件を満たす様に 決定される。速度の境界条件として Dirichlet 境界 条件が与えられ、物体内の物理量 $\left(q_{s}\right)$ は、

$$
\frac{\left|\phi_{f}\right| q_{s}+\left|\phi_{s}\right| q_{f}}{\left|\phi_{f}\right|+\left|\phi_{s}\right|}=q_{b}
$$

を満たす。圧力・流体率の物体上の境界条件とし て、勾配 0 を与える Neumann 境界条件が与えら れ、物体内の物理量は、

$$
q_{s}=q_{f}
$$

を満たす。ここで、法線方向の流体率の勾配が 0 となるため、接触角は 90 度となる。IBM による 物理量の修正は、連続の式を満たすために圧力 Poisson 方程式を解く前に適用される。

\section{4 時間積分法}

非圧縮性流体の解析手法として、速度の時間発 展と圧力 Poisson 方程式を分離した SMAC 型の 解法を用いた。時間積分法として、3 段 3 次精度 の TVD Runge-Kutta 法を採用し、各サブステップ 中で、圧力Poisson 方程式および物体の移動計算を 行うことで連続の式が満たされ、高精度な解析が 可能となる。

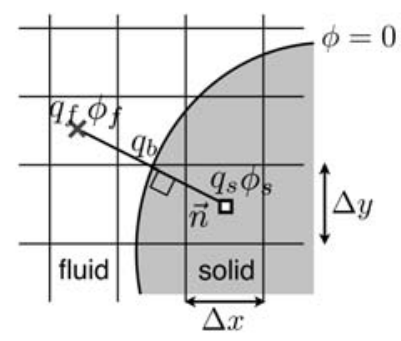

Fig. 1 Definitions of fluid and solid cells in the present immersed boundary method.

\section{NVIDIA CUDA}

\subsection{GPU を用いたカーネル計算}

科学技術計算を NVIDIA 製の GPU で行う場 合、C 言語を GPGPU 用に拡張した CUDA $[13,14]$ を用いてプログラムを開発する必 要がある。GPU の特徴として、1 チップ数千個 もの CUDA Core を搭載する SIMD 型の演算器 を搭載しており、非常に高い演算性能と広いメモ リバンド幅を持つ。CUDA で数值計算を行う場 合、計算はスレッドという単位で実行され、スレ ッドはスレッドブロックとグリッドという単位 で階層的に管理される。Fig. 2 にグリッドとブロ ックの概念図を描く。グリッドの中に碁盤の目の ようにブロックが配置されており。ブロックの中 にスレッドが管理されている。GPU 演算を高効 率で行うためには、局所的で例外処理のないデー タアクセスとマルチスレッドのデータ並列処理 が必要となる。本計算では、メモリ配置が連続的 な $\mathrm{x}$ 方向と、次に連続的な $\mathrm{y}$ 方向に CUDA の ブロックを設定し、 z 方向は for ループを回すこ とでステンシル計算を行った。 


\section{2 複数 GPU を用いた並列計算}

複数 GPU を用いた並列計算では、GPU 間のデ 一夕転送が必要となる。CUDA 4.0 の仕様では計算 機ノードをまたぐGPU 同士の直接の通信を行う事 ができないため、 $\mathrm{GPU} \rightarrow \mathrm{CPU} 、 \mathrm{CPU} \rightarrow \mathrm{CPU}$ 、 $\mathrm{CPU} \rightarrow \mathrm{GPU}$ のデバイス・ホスト間とホスト・ホス ト間の MPI を用いた 3 ステップのデータ転送が必 要となる。GPU 間のデー夕転送の概略図を Fig. 3 に示寸。本計算では、並列化手法として各 GPU に MPI のプロセスを 1 つ割り当てる Flat MPI によ る並列化を行った。
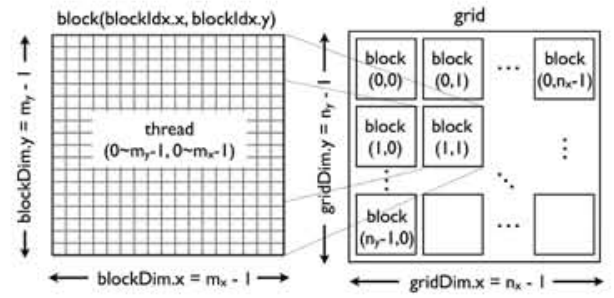

Fig. 2 The hierarchy of grids, blocks and threads in CUDA.

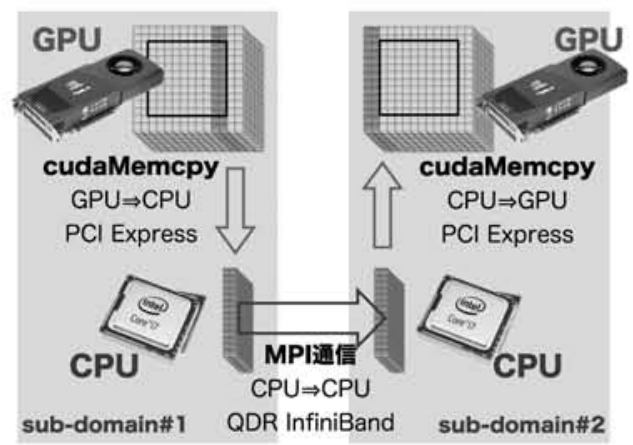

Fig. 3 MPI data transfer between GPUs.

\section{TSUBAME 2.5 の GPU を用いた性能測定} 東京工業大学のスパコン TSUBAME 2.0 は、 4,000 個以上の GPU(NVIDIA TESLA M2050) を搭 載し、LINPACK ベンチマークにおいて 1.192 PFLOPS を達成している[15]。更に、2013 年 9 月 に GPU を NVIDIA K20X へと更新することで、 TSUBAME 2.5 の理論演算性能は、単精度において 17 PFLOPS、倍精度で 5.7 PFLOPS となる。本章で は、TSUBAME 2.5 を用いて二相流解析手法の実効 性能測定を行う。

\section{1 気液二相流コードの実効性能測定}

液滴落下現象の計算を行い、気液二相流コードの 実効性能を測定した。計算領域として、 $x$ 軸・ $y$ 軸 方向に水平方向を、 $z$ 軸方向を高さ方向に割り当て、 計算領域サイズは $\left(L_{x}, L_{y}, L_{z}\right)=(40 \mathrm{~mm}, 40 \mathrm{~mm}, 20$ $\mathrm{mm})$ と設定した。液滴落下計算では、初期の液面 高さ $0.9 \mathrm{~mm}$ の薄い液膜に、直径 $4.8 \mathrm{~mm}$ の液滴を $2.8 \mathrm{~m} / \mathrm{s}$ の速度で衝突させた。 $2.8 \mathrm{~m} / \mathrm{s}$ は約 $400 \mathrm{~mm}$ の高さから液滴を落下させた時の速度に相当する。 気体と液体の物性值はそれぞれ密度 $\rho_{L}=1000$ $\mathrm{kg} / \mathrm{m}^{3} 、 \rho_{G}=1.25 \mathrm{~kg} / \mathrm{m}^{3}$ 、粘性 $\mu_{L}=1.7 \times 10^{-3} \mathrm{P} \mathrm{a} \cdot \mathrm{s} 、 \mu_{G}$ $=1.0 \times 10^{-6} \mathrm{~Pa} \cdot \mathrm{s}$ 、表面張力係数は $\sigma=5 \times 10^{-2} \mathrm{~N} / \mathrm{m}$ を設定し、液体の物性として擬似的なミルクの物性 （水と比較して粘性が倍、表面張力が半分程度）を 用いた。重力加速度は $9.8 \mathrm{~m} / \mathrm{s}$ を用いる。

Fig. 4 に液滴落下現象の計算結果を示寸。計算格 子は $\left(N_{x}, N_{y}, N_{z}\right)=(768,768,384)$ を設定し、 $1 \mathrm{GPU}$ あたりの格子点数として $(192,192,96) 、$ 計算資源 として 64 台の GPU を用いた。ミルククラウンの フィンガーは衝突後 $1.5 \mathrm{msec}$ 程度で生成され、液 滴の衝突によるジェット発生直後の不安定性によ り生じた凹凸がミルククラウンのフィンガーの種 となって成長していく様子が分かる。本計算では、

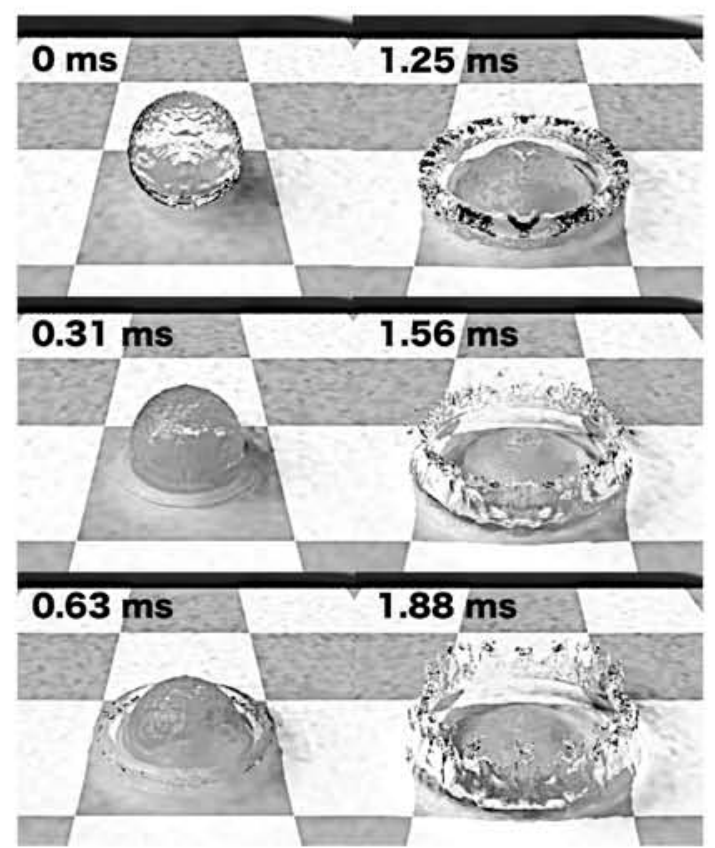

Fig. 4 Droplet impact to a thin milk layer. 
Krechetnikov らの実験結果[16]と同様の結果が得 られ、実験を良く再現できている。

Figs. 5-7 にGPU 数を変化させた時の 1 秒間に時 間更新できる格子点数の数 (MLUPS： mega lattice-updates per second）の弱スケーリングと強

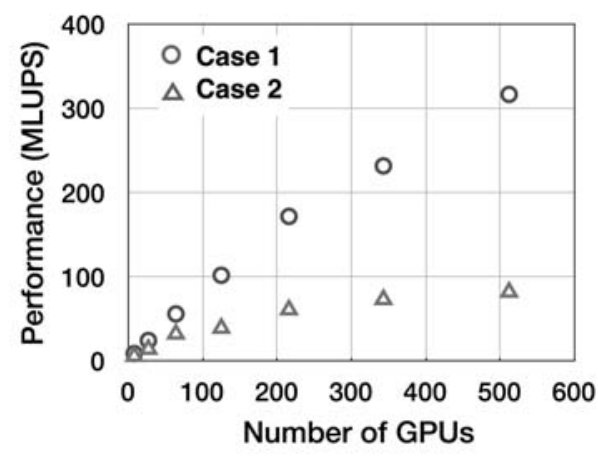

Fig. 5 Weak scalability in double precision.

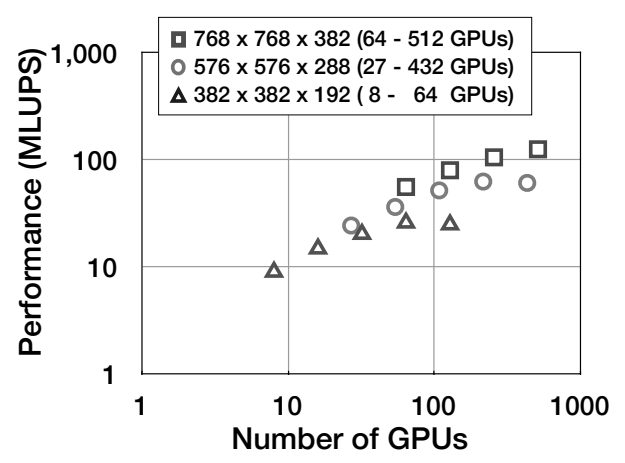

Fig. 6 Strong scalability of the case 1 in double precision.

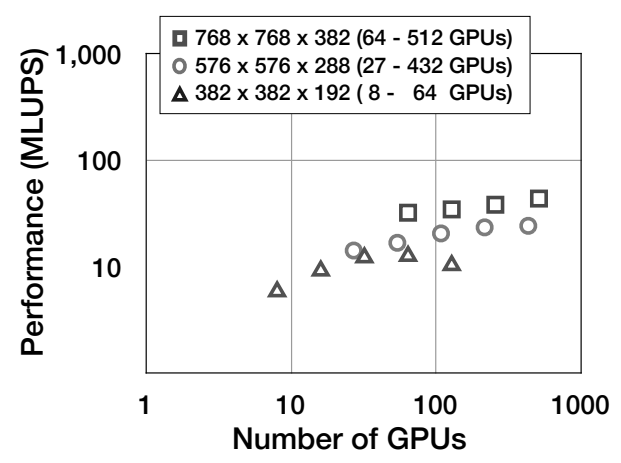

Fig. 7 Strong scalability of the case 2 in double precision.
スケーリングを示す。倍精度演算にて測定を行い、 圧力 Poisson 方程式の収束判定条件として、速度 場の発散が $10^{-6}$ 以下となるように設定した。計算 速度の測定条件として、液滴が界面に衝突するまで の比較的に収束が容易な条件である Case 1 と、液 滴が界面に衝突したときの収束が悪い条件である Case 2 を設定した。

Fig. 5 の弱スケーリングでは、1 GPUあたりの格 子点数を $\left(N_{x}, N_{y}, N_{z}\right)=(192,192 ， 96)$ と設定し、8 GPU から 512 GPU までの実行性能を測定した。

Case 1 の条件では、8 GPUで 9.0 MLUPS、64 GPU で 56 MLUPS、512 GPU で 317 MLUPS の結果が 得られ、512 GPU では 8 GPU に対して、35倍(効 率 55\%) の良いスケーリングが得られた。一方で、 Case 2 の条件においては、8 GPUで5.9 MLUPS、 64 GPU 32 MLUPS、 512 GPU で 82 MLUPS の 結果が得られ、512 GPU では 8 GPU に対して、14 倍(効率 22\%) の程度の高速化しか達成されていな い。このような速度低下の原因として、問題サイズ の増加と、最小格子スケールの細かな液滴の存在に よる収束性能の著しい低下が考えられる。

Figs. 6, 7 に Case 1 および Case 2 の強スケー リングの結果を示す。Case 1 の格子点数 $\left(\mathrm{N}_{\mathrm{x}}, \mathrm{N}_{\mathrm{y}}\right.$, $\left.\mathrm{N}_{\mathrm{z}}\right)=(382,382,192)$ の結果において、8 GPU の結 果と比較して16 GPU で 1.7 倍、32 GPU で 2.3 倍、 64 GPU で 2.9 倍の高速化が達成されたものの、 128 GPU においては 2.8 倍と速度の低下が確認さ れた。また、Case 2 においては、その傾向がより 顕著となり、並列数を増やすことによる効率的な高 速化が見込めない。

GPU を用いた並列計算に、大規模計算に適した 反復解法である AMG-BiCGSTAB 法を用いるこ とで、1 億格子を超える二相流解析の実施が可能で あるものの、このような収束性の悪化は今後の大き な課題である。

\section{5. 複雑物体を含む二相流計算}

移動物体を含む二相流計算として、回転板によ る水面の撹挥計算を行う。計算領域として、x 軸・ $\mathrm{y}$ 軸方向に水平方向を、 $\mathrm{z}$ 軸方向を高さ方向に割り 当て、領域サイズ $\left(L_{x}, L_{y}, L_{z}\right)=(0.5 \mathrm{~m}, 0.5 \mathrm{~m}, 0.5 \mathrm{~m})$ に対して、格子点数 $\left(N_{x}, N_{y}, N_{z}\right)=(512,512,512)$ 、 64 台の GPU を設定した。壁面は滑りなし境界条 件を与えた。気体・液体の物性值として、20 $\mathrm{C} の$ 空気と水の物性值を与え、初期值として水面高さ 
は $0.2 \mathrm{~m}$ に設定した。物体は計算領域中に 2 個 配置し、それぞれ逆方向に強制的に回転させる。 物体の大きさは、周方向、軸方向、厚さ方向に $(0.325 \mathrm{~m}, 0.08 \mathrm{~m}, 0.01 \mathrm{~m})$ とし、物体間の幅を回転板 の幅と同じ $0.08 \mathrm{~m}$ と設定した。回転数は $42 \mathrm{rpm}$ と $210 \mathrm{rpm}$ に設定した。

Figs. 8, 9 に気液界面、および手前側の回転板 の中心を通る $x-z$ 軸断面の流体率(VOF 值)を示 寸。それぞれの回転数において、板が気液界面に 打ち付けられることで、気液界面が大きく変形し、 細かなスプラッシュが飛んでいることが確認で きる。この様な気液界面が激しく掻き乱される現 象においても、本計算手法は安定に計算する事が 可能である。

\section{6. 物体と気液界面の連成解析}

固体と気液流体との連成問題として、球体の落 下問題の計算を行う。計算条件として、計算領域 $\left(L_{x}, L_{y}, L_{z}\right)=(0.3 \mathrm{~m}, 0.3 \mathrm{~m}, 0.3 \mathrm{~m})$ に対して、格子点 数 $\left(N_{x}, N_{y}, N_{z}\right)=(480,480,480)$ 、並列数 27 を設定 した。初期水面高さは $0.12 \mathrm{~m}$ とし、球体半径は $0.02 \mathrm{~m}$ 、質量は $10 \mathrm{~g}$ と設定し、簡略化のため球 の回転運動は考慮しない。球体の初期高さは $0.25 \mathrm{~m}$ 、初期速度を下向きに $5 \mathrm{~m} / \mathrm{s}$ と設定した。 固体と流体の連成解析では、固体に㗢く力の総和 を求める必要がある。固体に働く力は、IBM の物 体力の計算と同様に、物体近傍格子点上にて計算 される。物体の重心に作用する力は、Thrust ライ ブラリ[17] を用いることで GPU のデバイス上 にて高速な総和計算を行った。

Figs. 10,11 に計算結果を示寸。球体が気液界 面に衝突し液中に沈んだ後、浮力によって気液界 面まで浮き上がる様子が確認できる。また、気泡 の巻き込みや、しぶきを捉えた解像度で計算が実 施できていることが確認できる。以上の事より、 GPU を用いた計算により、1 億格子点程度の固気 液三相流の連成解析が容易に実施可能であること を示した。

\section{7. 結 言}

本研究では、GPU を用いた二相流解析手法に対 して、直交格子上にて複雑物体が表現可能な IBM を適用寸ることで、非常に高速な固気液三相流解 析手法の開発を行った。

液滴落下計算においては、計算格子 $\left(N_{x}, N_{y}, N_{z}\right)$

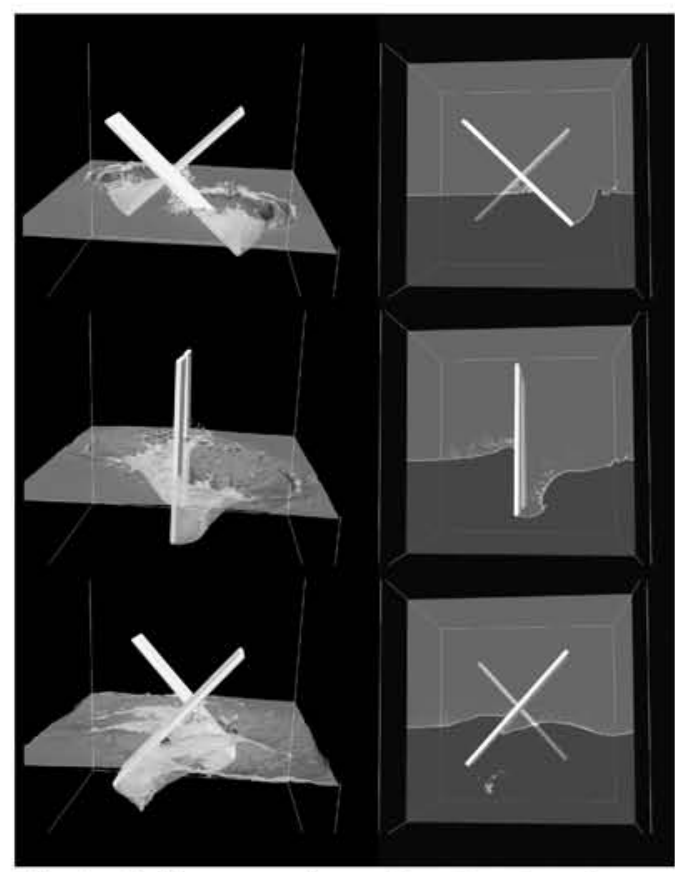

Fig. 8 Fluid-structure interaction of rotating plates at $42 \mathrm{rpm}$. (left : isosurface, right : VOF)

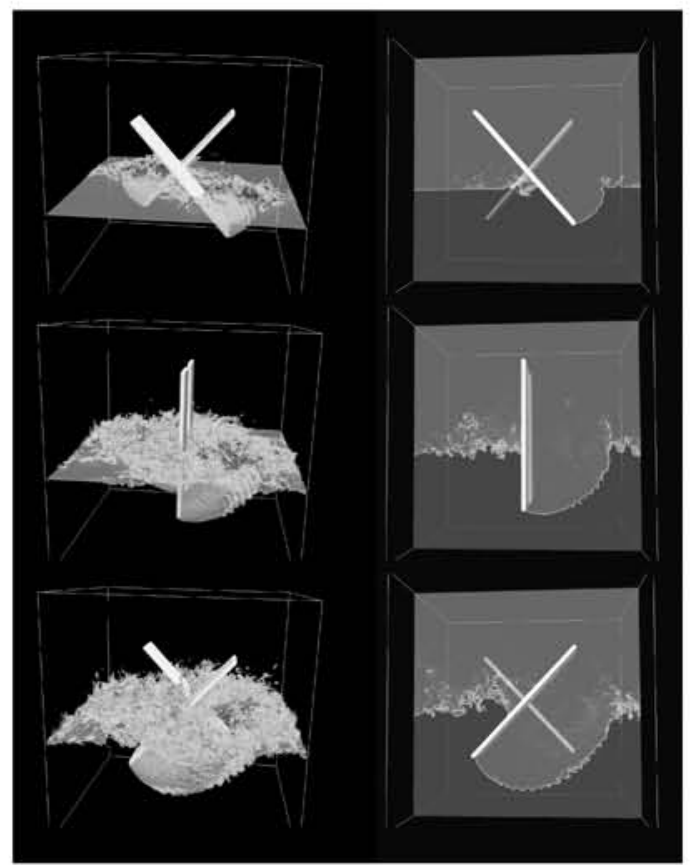

Fig. 9 Fluid-structure interaction of rotating plates at $210 \mathrm{rpm}$. (left : isosurface, right : VOF) 
$=(768,768,384:$ 約 2 億格子 $)$ の計算において、液 滴衝突後に形成されるミルククラウンのフィンガ 一を再現した。また、二相流計算手法の弱スケー リングの測定を行った結果、液滴が界面に衝突し た直後の非常に較しい条件下(Case 2)において、 512 台の GPU を用いた格子点数約 18 億の結果 では、82 MLUPS と 8 台の GPU を用いた結果に 対して 14 倍程度の高速化しか得られなかった。 しかしながら、10 億を超える格子点数においても 二相流計算が可能であることを示した。

移動物体と気液界面を含む固気液三相流解析で は、回転板による気液界面の摚汼計算においては 64 台の GPU を用いて格子点数 $512^{3}$ (約 1 億 3 千 万) の計算を、球体と気液界面の連成問題におい ては 27 台の GPU を用いて格子点数 $480^{3}$ (約 1 億 1 千万) の計算を行い、GPU を用いた並列計算 を行うことで 1 億格子点程度の流体アプリケーシ ヨンが容易に実施可能であることを示した。

しかしながら、今後実施される数百億以上の格 子点を用いたペタスケールのアプリケーションに おいて、行列の反復計算が大きなネックとなる事 が予測され、新たな二相流解析手法の提案が必要 である。

\section{謝 辞}

GPU 用の AMG-BiCGSTAB ライブラリを提 供して頂いたみずほ情報総研株式会社の永野勝 尋氏に深く感謝寸る。

本研究の一部は科学研究費補助金・若手研究(B) 課題番号 25870226 「次世代スパコンの高密度実 装に向けた超大規模乱流熱伝達計算」、科学研究 費補助金・基盤研究(B)課題番号 23360046「GPU スパコンによる気液二相流と物体の相互作用の 超大規模シミュレーション」、科学技術振興機構 CREST「次世代テクノロジーのモデル化・最適 化による低消費電力ハイパフォーマンス」および

「ポストペタスケール高性能計算に資するシス テムソフトウェア技術の創出」から支援を頂いた。 記して謝意を表す。

\section{Nomenclature}

FLOPS : floating-point operations per second

MLUPS: mega lattice-updates per second [Grid/s]

\section{Greek letters}

$\mu \quad$ : viscosity

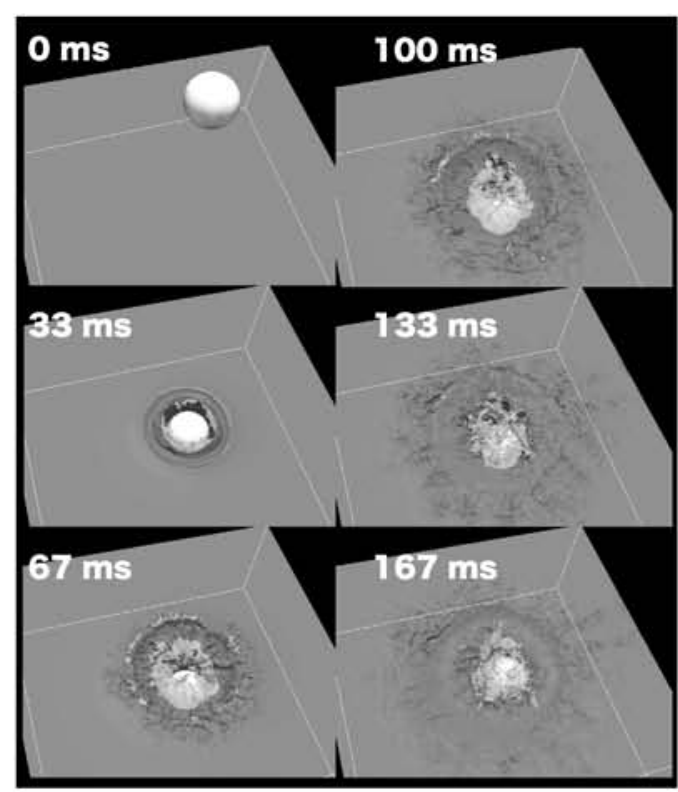

Fig. 10 Fluid-structure interaction of a falling sphere(top view).

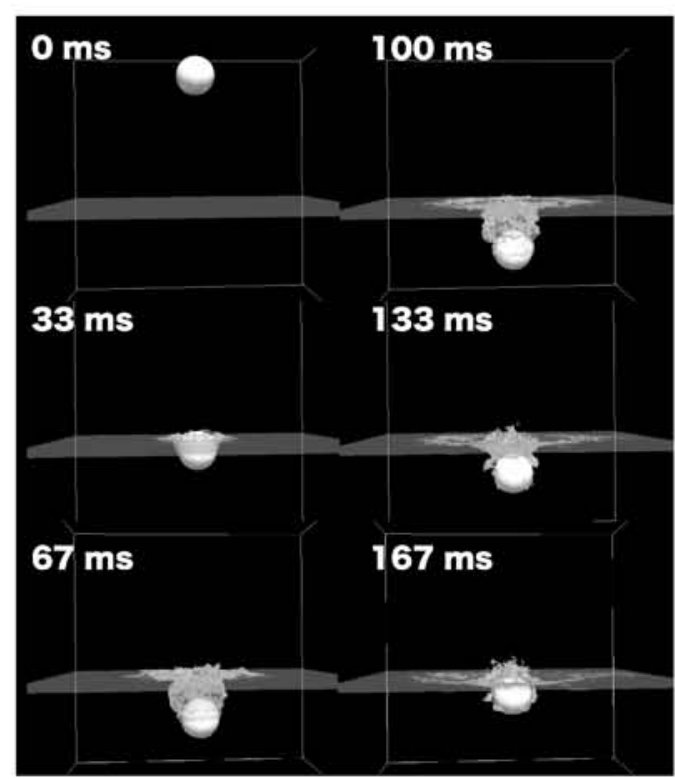

Fig. 11 Fluid-structure interaction of a falling sphere(side view).

$\begin{array}{llr}\rho & : \text { density } & {\left[\mathrm{kg} / \mathrm{m}^{3}\right]} \\ \sigma & : \text { surface tension } & {[\mathrm{N} / \mathrm{m}]}\end{array}$

\section{Subscripts}

G : gas phase

[Pa.s] $L \quad$ : liquid phase 


\section{参考文献}

[1] Shimokawabe, T., A oki, T., Takaki, T., Endo, T., Y amanaka, A., M aruyama, N., Nukada, A., and M atsuoka, S., Peta-scale Phase-Field Simulation for Dendritic Solidification on the TSU BA M E 2.0 Supercomputer, In Proceedings of 2011 International Conference for High Performance Computing, Networking, Storage and A nalysis, 1-11 (2011).

[2] Shimokawabe, T., A oki, T., M uroi, C., Ishida, J., K awano, K., Endo, T., Nukada, A., M aruyama, N., and Matsuoka, S., An 80-fold Speedup 15.0 TFlops Full GPU Acceleration of Non-Hydrostatic Weather Model ASUCA Production Code, In High Performance Computing, Networking, Storage and Analysis, 1-11 (2010).

[3] Open FOAM, http://www.openfoam.com

[4] Hablaa, F., M arschalla, H., Hinrichsena, O., Dietscheb, L., Jasakc, H., and Faverod, J.L., Numerical Simulation of $\mathrm{V}$ iscoelastic Two-Phase Flows using openFOAM, Journal of Computational Physics, Vol. 66(22), 5487-5496 (2011).

[5] Kim, J., Kim, D., and Choi, H., An Immersed-Boundary Finite-V olume Method for Simulations of Flow in Complex Geometries, Journal of Computational Physics, Vol. 171(1), 132-150 (2001).

[6] Peskin, C.S., The Immersed Boundary Method, A ct a Numerica, 479-517 (2002).

[7] Y okoi, K., Efficient Implementation of THINC Scheme: A Simple and Practical Smoothed VOF A lgorithm, J ournal of Computational Physics, $\mathrm{V}$ ol. 226(2), 1985-2002 (2007).

[8] Tan, N., A oki, T., Inoue, K., and Y oshitani, K., Numerical Simulation of Two-Phase Flow Driven by Rotating Object, Transactions of the Japan Society of Mechanical Engineers Series B, Vol. 77(781), 1699-1714 (2011).

[9] Jiang, G.S., and Shu, C.W., Efficient Implementation of Weighted ENO Schemes, Journal of Computational Physics, Vol. 126(1), 202-228 (1995).

[10] Shu, C.W., Essentially Non-Oscillatory and Weighted Essentially Non-Oscillatory Schemes for Hyperbolic Conservation Laws, NASA/CR-97-206253 ICASE Report, 97-65 (1997).

[11] Sugihara, K . and A oki, T., A cceleration of L arge Scale High Accurate Advection Calculation for Multiple GPUs and Its Strong Scalability, Transactions of JSCES, Paper No.20100018, (2010).

[12] Brackbill, J.U., Kothe, D.B., and Zemach, C., A Continuum M ethod for M odeling Surface Tension, Journal of Computational Physics, Vol. 100(2), 335-354 (1992).

[13] NVIDIA CUDA, http://www.nvidia.co.jp/object/cuda-jp.html

[14] Sanders, J. and K androt, E., CUDA by Example: An Introduction to General-Purpose GPU Programming, Addison-Wesley Professional (2010).

[15] Endo, T., Nukada, A., Matsuoka, S., and M aruyama, N., Linpack Evaluation on a Supercomputer with Heterogeneous A ccelerators, IEEE International Parallel \& Distributed Processing Symposium (IPDPS), 10-23 (2010).

[16] K rechetnikov, R. and Homsy, G.M., Crown-Forming Instability Phenomena in the Drop Splash Problem, J ournal of Colloid Interface Sci., V ol. 331, 555-559 (2009).

[17] Thrust, http://thrust.github.io 